\title{
Hyper-production of raw-starch-digesting en- zyme by mutant fungal strain and optimisation of solid by-products
}

\author{
Sản xuất cao sản enzyme phân hủy tinh bột sống bởi chủng đột biến và môi \\ trường tối ưu
}

Research article

$\mathrm{Vu}, \mathrm{Van} \mathrm{Hanh}^{1 *}$; Keun, Kim ${ }^{2}$

${ }^{1}$ Institute of Biotechnology, Vietnam Academy of Science and Technology, Hanoi 10600, Vietnam; ${ }^{2}$ Department of Bioscience and Biotechnology, University of Suwon, Hwaseong 445-743, Korea

\begin{abstract}
Selected fungal strain for production of raw-starch-digesting enzyme by solid state fermentation was improved by sequential exposures to $\gamma$-irradiation of $\mathrm{Co}^{60}$, ultraviolet and treatments with $\mathrm{N}$ methyl-N'-nitrosoguanidine. Mutant Aspergillus sp. CXN2-3A was chosen and its production of raw-starch-digesting enzyme (RSDE) was improved 2 folds higher than that of wild type. Optimal condition for the production of the enzyme using wheat bran as the substrate was accomplished for the CXN2-3A. With the optimal fermentation condition and the solid medium supplemented with urea and $\mathrm{NH}_{4} \mathrm{NO}_{3}, \mathrm{CoSO}_{4}$, Tween 80, 1\% glucose, CXN2-3A produced RSDE 19.23 folds higher than wild type cultured in pre-optimized condition and un-supplemented medium.
\end{abstract}

Chủng nấm chọn lọc sản xuất enzyme thủy phân tinh bột bằng cách lên men trạng thái rắn, chủng nấm được cái thiện bằng chiếu xạ tia cực tím, tia $C{ }^{60}$ và các phuoong pháp xủ lí với $N$-methyl-N'nitrosoguanidine. Mutant Aspergillus sp. CXN2-3A, đã đươc lựa chọn để sản xuất enzyme (RSDE) thủy phân tinh bột sống cải thiện cao hơn 2 lần so với chủng dại. Điều kiện tối uu cho việc sản xuất các enzyme bằng cách sủ dụng cám, lúa mì đã được thực hiện cho CXN2-3A. Với điều kiện lên men xốp tối uu và bổ sung urê và $\mathrm{NH}_{4} \mathrm{NO}_{3}, \mathrm{CoSO}_{4}$, Tween 80, $1 \%$ glucose, $\mathrm{CXN2}-3 \mathrm{~A}$ đã sản xuất RSDE cao gấp 19,23 lần so với kiểu dại ở cùng điều kiện.

Keywords: Aspergillus sp., N-methyl-N'-nitrosoguanidine, raw-starch-digesting enzyme, ultra violet, $\gamma$-irradiation of $\mathrm{Co}^{60}$

\section{Introduction}

Raw-starch-digesting enzyme (RSDE) composed of glucoamylase and other amylases is capable of hydrolyzing raw starch to glucose and other oligosaccharides at mild temperatures without requiring conventional two-step process of liquefaction and saccharification for ethanol fermentation (Kelly et al., 1995; Yamamoto, 1994). The use of RSDE provides more advantages in conversion of biomass into sugars than single enzyme and acid hydrolysis since it gives higher quality products, energy efficiency, safer working environment and last longer equipment (Matsumoto et al., 1982). RSDE was found in fungal strains such as Aspergillus sp., A. usami, Rhizopus sp., (Abe et al., 1988; Abu et al., 2005; Matsumoto et al.,
1982). The improvement of microbial strains using different mutagenic agents for the over-production of industrial products has been considered in commercial fermentation process (Parekh et al., 2000; Vu et al., 2010). Thermomyces lanuginosus was treated with irradiation of ultraviolet (UV) and N-methyl-N'-nitrosoguanidine (NTG) to improve $\alpha$-amylase and glucoamylase (Rubinder et al., 2002). A. niger was treated with $\gamma$-irradiation of $\mathrm{Co}^{60}$ for improvement of glucoamylase production (Rajoka et al., 2004). In this study, various mutagenic agents such as $\gamma$ ray of $\mathrm{Co}^{60}, \mathrm{UV}$, and NTG were combined to mutate fungal strains, then optimization of solid culture for hyperproduction of RSDE. 


\section{Materials and methods}

\subsection{Strain improvement by mutations}

Fungal strain C6.1 was found to be potent fungal strain for RSDE production and this strain was used for the strain improvement by mutation. The spores of C6.1 were harvested from 6 d-old spores grown on PDA plates and exposed to different doses $(0.5$ to $2.5 \mathrm{KGy}$ with $0.5 \mathrm{KGy}$ interval) of $\gamma$-ray. The survivors were grown by spreading $0.1 \mathrm{~mL}$ of treated spores on PDA plate containing $0.1 \%$ of raw starch-RBB and then incubated at $30^{\circ} \mathrm{C}$ for $4 \div 7$ days. Based upon the clearing zones surrounding the colonies, $\gamma$-ray mutant X2 was selected and was again treated with $\gamma$-ray of $2 \mathrm{KGy}$. According to Kuhad et al. (1994), the best $\gamma$-ray mutant X2 -2 was continuously exposed to UV irradiation at $30 \mathrm{~W}$ in a distance of $50 \mathrm{~cm}$ for $5 \div 60 \mathrm{~min}$, where at $5 \mathrm{~min}$ interval the spores were taken out to test. The best mutant strain UV1 was sequentially treated with four cycles of NTG solution $(100 \mu \mathrm{g} /$ $\mathrm{ml}$ in $0.2 \mathrm{M}$ citrate buffer, $\mathrm{pH} \mathrm{5)}$ for $10 \div 60 \mathrm{~min}$. After treatment with various mutagenic agents, many mutant strains were screened. Finally, one best mutant strain CXN2-3a was taken for further study.

\subsection{Determination of RSDE activity}

The RSDE activity was determined as described in previous study (Vu et al., 2010). One unit (U) of RSDE activity was defined as amount of enzyme in $1 \mathrm{~mL}$, which liberates one $\mu \mathrm{mol}$ of glucose, per min, from raw rice starch (Miller, 1959).

\subsection{Preparation of seeding culture}

In a $250 \mathrm{~mL}$ Erlenmeyer flask containing $10 \mathrm{~g}$ of rice bran

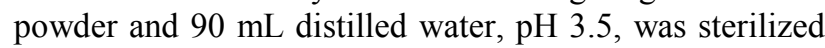
at $121^{\circ} \mathrm{C}$ for $20 \mathrm{~min}$, and then cooled. To this, one plug $(1$ $\mathrm{x} 1 \mathrm{~cm}^{2}$ ) of $7 \mathrm{~d}$-old conidia-mycelia were inoculated and incubated at $30^{\circ} \mathrm{C}$ in a shaker operated at $200 \mathrm{rpm}$ for 1 day.

\subsection{Solid state of fermentation (SSF)}

A $500 \mathrm{~mL}$ Erlenmeyer flask containing $20 \mathrm{~g}$ of rice bran with $33.3 \%(\mathrm{v} / \mathrm{w})$ of moisture was plugged with cotton and sterilized for SSF.

\subsection{Optimization of SSF}

The SSF was carried out to study the effect of various parameters required for the optimum production of RSDE by selected mutant CXN2-3A. Substrate (wheat bran, rice husk, rice bran, saw dust), moisture $(20,30,40,50,60,70$ and $80 \%, \mathrm{v} / \mathrm{w})$, culture temperature $(20,25,30,35,40$, and $\left.45^{\mathrm{oC}}\right)$, initial $\mathrm{pH}$ of solid culture $(3.0,3.5,4.0,4.5$, $5.0,5.5,6.0,6.5,7.0)$, culture time $(2 \div 6$ days $)$, aeration area $(15,20,25,30,35,40$, and $45 \mathrm{~g}$ of moistened wheat bran in a $500 \mathrm{~mL}$ Erlenmeyer flask), age of seeding culture $(1 \div 4$ days $)$, inoculum size $(10,15,20,25,30,35$, $40,45$, and $50 \%, v / w)$ were the parameters to be optimized.
The examined additives were carbon sources of glucose, maltose, rice starch, sucrose, and corn, each at $1 \%$; nitrogen sources of urea, yeast extract, tryptone, tryptic soy, peptone, nutrient broth, skim milk, casamino acids, soytone, malt extract, $\mathrm{NH}_{4} \mathrm{Cl}$, and $\mathrm{NH}_{4} \mathrm{NO}_{3}$, each at $1 \%$; metal salts of $\mathrm{CaCl}_{2}, \mathrm{MgCl}_{2}, \mathrm{MnCl}_{2}, \mathrm{CuSO}_{4}, \mathrm{CoSO}_{4}, \mathrm{FeSO}_{4}$, $\mathrm{ZnSO}_{4}, \mathrm{NaNO}_{3}$ and $\mathrm{KCl}$, each at $2.5 \mathrm{mM}$; surfactant of Tween 20, Tween 80 , Trixton-X100, each at $0.5 \%$ while SDS, and EDTA, each at $0.4 \mathrm{mM}$. SSF was carried out at $30^{\circ} \mathrm{C}$ for 3 days with wheat bran containing $33 \%$ of initial moisture, which was inoculated with $10 \%(\mathrm{v} / \mathrm{w})$ of $1 \mathrm{~d}$-old seeding culture.

\subsection{Ethanol production by simultaneous sac- charification and fermentation using RSDE and Saccharomyces cerevisiae}

Uncooked rice winery waste rice-wine-cake slurry containing $25.73 \%(\mathrm{w} / \mathrm{v})$ solid was used for simultaneous saccharification and fermentation (SSF). The SSF was conducted in a 100 liters fermentor containing $50 \mathrm{~L}$ slurry, $\mathrm{pH} 3.5$, with crude enzyme of fungal strain of mutant CXN2-3a with 1.13 Unit of RSDE/ gds (gram dried substrate). To the slurry, yeast cells of $S$. cerevisiae KV25 was inoculated to make initial cell number of $2.5 \mathrm{x}$ $10^{7} / \mathrm{mL}$, incubated at $30^{\circ} \mathrm{C}$ for 5 days, and the ethanol formed was determined.

\section{Results and discussion}

\subsection{Screening and selection of a mutant strain}

Selected fungal strain C6.1 was treated with two cycles of $\gamma$-irradiation. The best $\gamma$-ray-mutant strain X2-2 was then treated with UV irradiation. The best mutant UV strain was sequentially treated with four cycles of NTG. Finally, mutant strain CXN2-3A produced the highest activities of RSDE was selected. The mutant strain CXN2-3A exhibited 2.7 folds improved activity than that of wild type. The mutant CXN2-3A was identified as Aspergillus sp. with $99 \%$ of homology by sequencing the internal transcribed spacers.

Mutant strain CXN2-3A produced a high level of RSDE was obtained by mutagenic method and the strain was also stable for a long period to produce RSDE. In the past, the use of mutagenic agents such as $\gamma$-ray, UV, and NTG for hyper-production of industrial products has been reported but the repeated and sequential use of all of these mutagenic agents as shown in this study was not documented yet. A mutant Thermomyces lanuginosus obtained after treatment with three cycles of UV and NTG produced $\alpha$-amylase and glucoamylase 7 - and 3-folds, respectively, higher than those of wild type (Rubinder et al., 2002). Mutant $A$. niger created by $\gamma$-irradiation produced glucoamylase 2.0-2.5 folds higher than those of wild type (Rajoka et al., 2004). Vu et al. (2009) used repeated and sequential mutagenesis to mutate fungal strain, as a result, the mutant strain secreted more RSDE activity than that of wild type. 


\subsection{Optimal SSF-condition for the production of RSDE by mutant Aspergillus sp. CXN2-3A}

Substrate: Among several solid media, rice bran showed the highest production of RSDE $(62.2 \mathrm{U} / \mathrm{g})$ while ricehusk, and saw dust exhibited lower enzyme production. Of the various solid substrates used in this study, rice bran proved to be suitable for the colonization of Aspergillus sp. CXN2-3A as indication by the maximum visible growth on medium and the highest enzyme yield.

Initial moisture content: Moistened solid medium containing $50 \%$ moisture content yielded the highest level of RSDE (62.2 U/g), while those containing 20, 30, 40,60, 70 , and $80 \%$ produced lower activity. In SSF, moisture level plays an important role in biosynthesis and secretion of the enzymes. High moisture results in decreased substrate porosity as well as reduced oxygen penetration $(\mathrm{Vu}$ et al., 2010) but low moisture leads to poor microbial growth and poor accessibility to nutrient (Pandey, 1992). Aspergillus sp. A3 at $80 \%$ of moisture using wheat bran (Ellaiah et al., 2002)], Rhizopus nigricans PCSIR18 at 60 $\%$ of moisture (Mahmmod et al., 1997).

The optimal temperature for the highest production of RSDE was at $30^{\circ} \mathrm{C}$ (Table 1). The optimal growth temperature varied with different fungi such as at $35^{\circ} \mathrm{C}$ for $A$. niger NRRL 3112 and $A$. niger NRRL 337 but at $30^{\circ} \mathrm{C}$ for Aspergillus sp. A3 (Ellaiah et al., 2002). Incubation temperature at $30^{\circ} \mathrm{C}$ proved to be the best one for $\alpha$-amylase production by $A$. oryzae but higher temperature affected harmfully the enzyme production (Ramachandran et al., 2004).

Among the physical parameters, the $\mathrm{pH}$ of the growth medium plays an important role by inducing morphological change in microorganism and in enzyme secretion. The high production of RSDE was observed at medium$\mathrm{pH}$ of 4.5 (Table 1) and the production of RSDE was influenced by $\mathrm{pH}$, which is very important in growth of microorganism and its metabolic activities. The metabolic activities of the microorganisms are very sensitive to changes in $\mathrm{pH}$ and also optimal $\mathrm{pH}$ varies with different microorganisms and enzymes. Thus, A. niger NCIM1245 produced maximum glucoamylase yields at $\mathrm{pH} 4.7$ (Pandey \& Radhakrishnan, 1993) but Aspergillus sp. A3 at pH 5 (Ellaiah et al., 2002).

In the growth-related production of enzymes, after 3 days of incubation, the highest production $(61.0 \mathrm{U} / \mathrm{g})$ of RSDE was observed (Table 1). Incubation beyond 3 days was undesirable as this resulted in decreased enzyme production.

Aeration area (g solid medium / $250 \mathrm{~mL}$ Erlenmeyer flask): Amount of moistened rice bran to flask volume affects the porosity and aeration differently. It was proven that the high production of RSDE $(65.0 \mathrm{U} / \mathrm{g})$ was observed at $(15 \mathrm{~g} / 500 \mathrm{~mL}$ flask), therefore, this ratio was used for further study. Similar findings were reported by Bhatti (2007) and Ellaiah (2002), where ratio of substrate mass to flask volume of $1: 50$ was optimal for glucoamylase production by Fusarium solani and Aspergillus sp. A3.
Age of seeding culture: It was found that the seeding culture age of 2 days was suitable for inoculation and enzyme production but beyond 2 days was undesirable as these results in decreased enzyme yield. As a result, the highest production of RSDE $(70.5 \mathrm{U} / \mathrm{g})$ was observed (Table 1).

Inoculum size: The maximum production $(78.5 \mathrm{U} / \mathrm{g})$ was observed at inoculum size of $25 \%(\mathrm{v} / \mathrm{w})$. This inoculum size was used for further study. Inoculum density is an important factor in an SSF process.

Effect of various medium-additives on the enzyme production: From the achieved data of enzyme production (Table 1), it was found that with the single addition of carbon source such as sucrose, maltose, rice starch and corn starch into the solid medium, there was a slight enhancement in the enzyme production of Aspergillus sp. CXN2-3A but with the addition of glucose to the medium, there was a significant enhancement of enzyme production $(83.52 \mathrm{U} / \mathrm{g})$. In other reports, glucoamylase production by fungi in wheat bran was enhanced by supplementation with sucrose (Anto et al., 2006), fructose (Ellaiah et al., 2002), starch (Bhatti et al., 2007; Ramachandran et al., 2004), but the improvement was not observed in maltose supplement (Ramachandran et al., 2004).

It was found that the addition of urea or $\mathrm{NH}_{4} \mathrm{NO}_{3}$ resulted in the highest RSDE production of 95.5 and $102.2 \mathrm{U} / \mathrm{g}$, respectively, while other nitrogen sources showed a little enhancement or an inhibition of enzyme production (Table 1). The $\left(\mathrm{NH}_{4}\right)_{2} \mathrm{SO}_{4}$ enhanced glucoamylase production by $A$. awamori (Anto et al., 2006), yeast extract and peptone enhanced glucoamylase production (Bertolin et al., 2003; Ramachandran et al., 2004) urea, ammonium salts enhanced glucoamylase production (Bhatti et al., 2007; Ellaiah et al., 2002), (Ramachandran et al., 2004).

The use of surfactants and fatty acids is well documented to increase the production of hydrolytic enzymes (Singh et al., 1991). Surfactants have the potential to enhance microbial growth in SSF by promoting the penetration of water into the solid substrate matrix that leads to an increase in surface area (Asgher et al., 2006). Herein, we found that Tween 80 enhanced the most highly the production of RSDE $(85.7 \mathrm{U} / \mathrm{g})$.

It is $\mathrm{Cu}^{2+}$ which is an essential metal ion to all organisms (Silva \& Williams, 1993). An addition calcium ions onto medium enhanced $\alpha$-amylase activity (Nirmala \& Muralikrishna, 2003), improved glucoamylase activity (Anto et al., 2006). In the present study, it was shown that Co$\mathrm{SO}_{4}$ enhanced the most highly the RSDE production $(88.52 \mathrm{U} / \mathrm{g})$.

Production of RSDE at optimal condition with solid medium supplemented with additives: Optimal culture condition of solid rice bran for production of RSDE was accomplished, which were at $30^{\circ} \mathrm{C}$, medium- $\mathrm{pH}$ of 4.5 , moisture content of $50 \%, 2$ d-old seeding-culture age, inoculum size of $25 \%$, nitrogen additives of $1 \%$ urea and $1 \% \mathrm{NH}_{4} \mathrm{NO}_{3}$, carbon additive of $1 \%$ glucose, metal additive of $2.5 \mathrm{mM} \mathrm{CoSO}$, surfactant additive of $0.05 \%$ 
Tween 80, substrate mass to Erlenmeyer flask volume of $3: 100(\mathrm{w} / \mathrm{v})$. With this condition, the production of RSDE was $548.2 \mathrm{U} / \mathrm{g}$. The results showed that the production of RSDE by mutant Aspergillus sp. CXN2-3A was improved 19.23 folds higher than that of wild type produced in pre-optimized condition and basal medium without additives (Table 1). Also this $581.41 \mathrm{U} / \mathrm{g}$ of RSDE of Aspergillus sp. CXN2-3A was much higher than those of commercial enzyme preparation from Rhizopus sp. (102.3 U/g) and A. usamii $(94.5 \mathrm{U} / \mathrm{g})$.

Table 1. Effect of different factors on the RSDE production

\begin{tabular}{|c|c|c|c|c|c|c|c|c|c|}
\hline Moisture (\%) & 20 & 40 & 50 & 60 & 80 & & & & \\
\hline $\mathrm{U} / \mathrm{g}$ & 47.7 & 53.99 & 60.2 & 56.45 & 45.0 & & & & \\
\hline Temp. $\left({ }^{\circ} \mathrm{C}\right)$ & 20 & 25 & 30 & 35 & 40 & 45 & & & \\
\hline $\mathrm{U} / \mathrm{g}$ & 40 & 45 & 53.1 & 42 & 37.2 & 33.1 & & & \\
\hline pH of medium & 3 & 4 & 5 & 6 & 7 & 8 & & & \\
\hline $\mathrm{U} / \mathrm{g}$ & 36.3 & 60.4 & 58 & 53 & 50 & 47 & & & \\
\hline Culture time (day) & 2 & 3 & 4 & 5 & 6 & & & & \\
\hline $\mathrm{U} / \mathrm{g}$ & 20 & 61 & 57.83 & 52.5 & 43.41 & & & & \\
\hline $\begin{array}{l}\text { Solid medium }(\mathrm{g}) / \\
\text { Flask }(250 \mathrm{~mL})\end{array}$ & 15 & 20 & 360 & 40 & $\mathbf{5 0}$ & & & & \\
\hline $\mathrm{U} / \mathrm{g}$ & 65 & 62.2 & 45.5 & 38.2 & 37.2 & & & & \\
\hline $\begin{array}{l}\text { Seeding age (day) } \\
\mathrm{U} / \mathrm{g}\end{array}$ & $\begin{array}{c}1 \\
65.2\end{array}$ & $\begin{array}{c}\mathbf{2} \\
70.5\end{array}$ & $\begin{array}{c}3 \\
65.3\end{array}$ & $\begin{array}{c}\mathbf{4} \\
42\end{array}$ & & & & & \\
\hline $\begin{array}{l}\text { Inoculumn size } \\
(\%, v / w)\end{array}$ & 10 & 20 & 30 & 40 & 50 & & & & \\
\hline $\mathrm{U} / \mathrm{g}$ & 75 & 73.2 & 78.5 & 68.3 & 62.5 & & & & \\
\hline Carbon additive & None & glucose & $\begin{array}{l}\text { corn- } \\
\text { starch }\end{array}$ & $\begin{array}{l}\text { su- } \\
\text { crose }\end{array}$ & $\begin{array}{l}\text { malt- } \\
\text { ose }\end{array}$ & rice & & & \\
\hline $\mathrm{U} / \mathrm{g}$ & 78.5 & 81.5 & 80.3 & 79.3 & 13.5 & 81.3 & & & \\
\hline Nitrogen additive & None & $\mathrm{NH}_{4} \mathrm{Cl}$ & Urea & $\begin{array}{l}\text { Malt } \\
\text { extract }\end{array}$ & Casein & $\begin{array}{l}\text { Yeast } \\
\text { extract }\end{array}$ & $\begin{array}{l}\text { Tryp } \\
\text { ton }\end{array}$ & $\begin{array}{l}\text { Tryptic } \\
\text { soy }\end{array}$ & $\begin{array}{l}\text { Soy- } \\
\text { tone }\end{array}$ \\
\hline $\mathrm{U} / \mathrm{g}$ & 78.2 & 74.5 & 95.5 & 78.9 & 74.4 & 78.5 & 78.5 & 76.5 & 80.5 \\
\hline $\begin{array}{l}\text { Nitrogen additive } \\
\text { (continued) }\end{array}$ & $\mathrm{NH}_{4} \mathrm{NO}_{3}$ & $\begin{array}{l}\text { Pep- } \\
\text { tone }\end{array}$ & $\begin{array}{l}\text { Skim } \\
\text { milk }\end{array}$ & NB & & & & & \\
\hline $\mathrm{U} / \mathrm{g}$ & 102.2 & 79.5 & 776.5 & 97.5 & & & & & \\
\hline Surfactant & None & $\begin{array}{c}\text { Tween } \\
-20\end{array}$ & $\begin{array}{c}\text { Tween- } \\
80\end{array}$ & $\begin{array}{l}\text { Triton } \\
\text { X100 }\end{array}$ & EDTA & SDS & & & \\
\hline $\mathrm{U} / \mathrm{g}$ & 78.2 & 81.5 & 85.5 & 78.5 & 98.5 & 70.2 & & & \\
\hline $\begin{array}{l}\text { Metal ions addi- } \\
\text { tives }\end{array}$ & None & $\mathrm{Mg}^{2+}$ & $\mathrm{Mn}^{2+}$ & $\mathrm{Cu}^{2+}$ & $\mathrm{Co}^{2+}$ & $\mathrm{Fe}^{2+}$ & Zn2+ & $\mathbf{K}^{+}$ & $\mathrm{Ca}^{2+}$ \\
\hline $\mathrm{U} / \mathrm{g}$ & 78.2 & 74.5 & 83.2 & 85.2 & 90.3 & 56.6 & 557.5 & 62.1 & 81.3 \\
\hline Parameter & $\begin{array}{l}\text { WT in } \\
\text { basM }\end{array}$ & $\begin{array}{l}\text { MT in } \\
\text { basM }\end{array}$ & $\begin{array}{l}\text { MT in } \\
\text { opt, }\end{array}$ & & & & & & \\
\hline $\mathrm{U} / \mathrm{g}$ & 28.5 & 58.7 & 548.2 & & & & & & \\
\hline
\end{tabular}

WT in basM, wild type of strain produced RSDE in basal medium; MT in basM, Mutant strain produced RSDE in basal medium; MT in opt, Mutant strain produced RSDE in optimized medium.

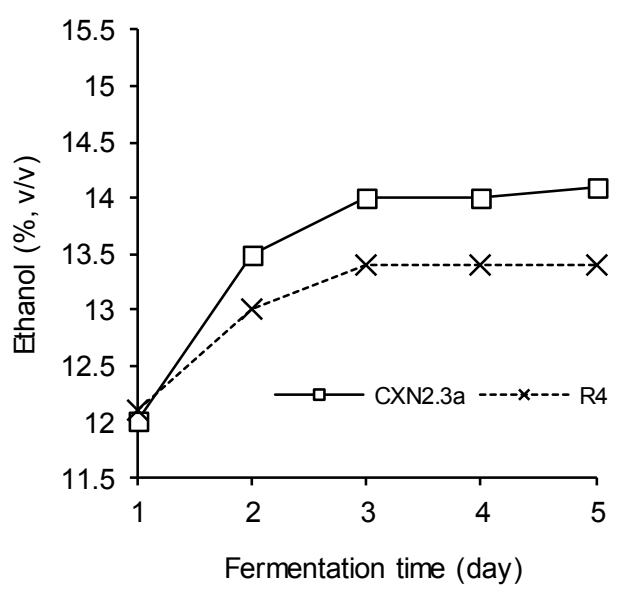

Figure 1. SSF of RWC slurry treated with crude enzyme of fungal trains and $S$. cerevisiae $\mathrm{KV}-25$

SSF of RWC in a $100 \mathrm{~L}$ fermentor using crude RSDE of mutant fungal strains of CXN2-3a, together with $S$. cerevisiae $\mathrm{KV}-25$. R4 (commercial enzyme) used as control

Ethanol production from raw starch using crude RSDE of mutant CXN2-3A by SSF: The ethanol production from winery waste rice-wine-cake (RWC) slurry by SSF was conducted in a 100 liters fermentor at $30^{\circ} \mathrm{C}$. RSDE from Aspergillus sp CXN2-3A was excellent to treat raw-starch with high efficiency of ethanol conversion. The SSF using the enzyme of Aspergillus sp. CXN2-3A produced $15.82 \%(\mathrm{v} / \mathrm{v})$ ethanol from $25.73 \%$ of solid, after $96 \mathrm{~h}$ (Fig. 1). Also the ethanol fermentation efficiency using 
the enzyme of Aspergillus sp. CXN2-3A was $92.7 \div$ $94.0 \%$, which is very high efficiency of ethanol production. The SSF process was carried out without cooking and economically more attractive.

\section{Conclusion}

It can be concluded that fungal strain CXN2-3A mutant is a potential microorganism for production of RSDE. The RSDE produced by the mutant strain can be applied successful ethanol production from slurry containing a high level of raw starch by SSF without application of liquefying enzyme and cooking. On the other hand, the results provided valuable information of using novel efficient mutation method to obtain mutation that produced a high level of RSDE.

\section{References}

[1] Abe, J.I., Bergmann, F.W., Obata, K., Hizukuri, S. 1988. Production of the raw starch digesting amylase of Aspergillus sp. K-27. Appl Microbiol Biotechnol 27: 447-450.

[2] Abu, E.A., Ado, S.A., \& James, D.B. 2005. Raw starch degrading amylase production by mixed culture of Aspergillus niger and S. cerevisiae grown on sorghum pomace. Afr. J. Bioethanol 4: 785-790.

[3] Anto, H., Trivedi, U.B., Patel, K.C. 2006. Glucoamylase production by solid state fermentation using rice flask manufacturing waste products as substrate. Biores Technol 97: 1161-1166.

[4] Asgher, M., Asad, M.J., \& Legge, R.L. 2006. Enhanced lignin peroxides synthesis by Phanerichaete chrysosporium in solid state bioprocessing of a lignocellosis substrate. World J Microbiol. Biotechnol 22: 449-453.

[5] Bertolin, T.E., Schmidell, W., Maiorano A.E., Casara, J., and Costa, J.A.V. 2003. Influence of carbon, nitrogen and phosphorous source on glucoamylase production by Aspergillus niger in solid state fermentation. Z. Naturforsch. 58c: 708-712.

[6] Bhatti, H.N., Mohammad, H.R., Rakhshanda, N., Muhammad, A., Raheela, P., Abdul, J. 2007. Optimization of media for enhanced glucoamyalase production in solid state fermentation by Fusarium solani. Food technol Biotechnol 45: 51-56.

[7] Ellaiah, P., Adinarayana, K., Bhavani, Y., Padmaja, P., Srinivasulu, B. 2002. Optimization of process parameters for glucoamylase production under solid state fermentation by a newly isolated Aspergillus species. Process Biochem 38: 615-620.

[8] Kelly, C.T., McTigue, M.A., Doyle, E.M., Fogarty, W.M. (1995). The raw starch degrading alkaline amylase of Bacillus sp. IMD 370. J Ind Microbiol 15: 446-448.

[9] Kuhad, R.C., Kumar, M., Singh, A. 1994. A hypercellulolytic mutant of Fusarium oxysporum. Lett Appl Microbiol 19: 397-400.
[10] Mahmmod, A., Airengzeb, M., Baig, R., Ahmad, M.A. 1997. Production of amyloglucosidase by $A s-$ pergillus niger under different cultivation regimes Pak J Biochem Mol Biol 30: 49-54.

[11] Matsumoto, N., Fukushi, O., Miyanaga, M., Kakihara, K., Nakajima, E., Yoshizumi, H. 1982. Industrialization of non-cooking system for alcoholic fermentation from grains. Agric Biol Chem 18: 1549-1558.

[12] Miller, G.L. 1959. Use of dinitrosalicylic acid reagent for determination of reducing sugar. Anal Chem 31: 426-428.

[13] Nirmala, M., Muralikrishna, G. 2003. Three amylases from malted finger millet (Ragi, Eleusine coracana, Indaf-15)-purification and partial characterization. Phytochemist 62: 21-30.

[14] Pandey, A. 1992. Production of starch saccharifying enzyme (glucoamylase) in solid cultures. Starch 44 : 75-77.

[15] Pandey, A., Radhakrishnan, S. 1993. The production of glucoamylase by Aspergillus niger NCIM 1245. Process Biochem 38: 305-309.

[16] Parekh, S., Vinci, V.A., Strobel, R.J. 2000. Improvement of microbial strains and fermentation processes. Appl Microbiol Biotechnol 54: 287-301.

[17] Rajoka, M.I., Yasmin, A., Latif, F. 2004. Kinetics of enhanced ethanol productivity using raw starch hydrolyzing glucoamylase from Aspergillus niger mutant produced in solid state fermentation. Lett Appl Microbiol 39: 13-18.

[18] Ramachandran, S., Patel, A.K., Nampoothiri, K.M., Francis, F., Nagy, V., Szakacs, G. 2004. Coconut oil cake -a potential raw material for the production of $\alpha$-amylase. Biores Technol 93: 169-174

[19] Rubinder, K., Chadha, B.S., Singh, N., Saini, H.S., Singh, S. 2002. Amylase hyperproduction by deregulated mutants of the thermophilic fungus Thermomyces lanuginosus. J Ind Microbiol Biotechnol 29: 70-74.

[20] Silva, J., Williams, R. (Eds.). 1993. The biological chemistry of the elements. New York, USA: Clarendon Press.

[21] Singh, A., Abidi, A.B., Darmwal, N.S., Agrawal, A.K. 1991. Influence of nutritional factors of cellulase production from natural lignocellulosic residues by Aspergillus niger. Agric Biol Res 7: 19-27.

[22] Vu, V.H., Pham, T.A., Kim, K. 2010. Improvement of a fungal strain by repeated and sequential mutagenesis and optimization of solid-state fermentation for the hyper-production of raw-starch-digesting enzyme. J Microbiol Biotechnol 20(4): 718-726.

[23] Yamamoto, S. 1994. Raw starch-digesting enzyme (maltooligosaccharide producing type) of Zoogeloea ramigera. J Appl Glycoscience 41: 283-289. 